Јелена М. Газдић

Универзитет Црне Горе

Филолошки факултет у Никшићу

Студијски програм за српски језик

и јужнословенске књижевности

https://doi.org/10.18485/ai fonefonosj.2020.ch9

811.163.41'271.16(497.16 Пљевља)

\title{
КОНТИНУАНТИ ЈАТА У ГОВОРНОЈ ПРАКСИ НА СЈЕВЕРУ ЦРНЕ ГОРЕ (ПЉЕВЉА) И ПРАВОПИСНА НОРМА
}

У раду смо се бавили континуантима старог (дугог и кратког) вокала jam иза сонанта $p$ у говору Пљеваља. Циљ рада је сагледавање односа ортографске норме и њене ортоепске реализације, а користили смо метод анкете. Разлог за продирање нормативног је наспрам ранијег доминантног $e$, у позицији сонант $p+$ кратко јат, можемо тражити у утицају норме. Спорадично продирање нестандардних облика са ије на мјесту некадашњег кратког јата можемо објаснити деценијским наметањем ненормативних ијекавизама у појединим медијима, као и дјеловањем аналогије према исфорсираним облицима са ије у рефлексима дугог јата у школским уџбеницима у оним примјерима гдје норма дозвољава дублете.

Кључне ријечи: дуго јат, кратко јат, сонант $p$, Пљевља

0. Вокал $\mathrm{b}$ представља једну од најсложенијих фонематских јединица у историји српског језика 1) зато што не знамо његову основну гласовну вриједност; 2) зато што су се његове измјене у различитим крајевима

1 jelena.gazdic@gmail.com 
извршиле у различито вријеме, па у писаним споменицима у прелазним подручјима наилазимо и на њихово мијешање; 3) зато што имамо различите гласовне фонематске замјене прасловенског јата како у свим словенским језицима тако и у српском језику (Стојановић 2005: 82). Као посебна фонема jam је био у употреби до 13-14 вијека, кад је почела његова замјена другим гласовним вриједностима. У зависности од дужине слога и гласовног окружења у ијекавском изговору јављају се четири рефлекса jama: uje, je, е и и. Основна правила ијекавског изговора рефлекса старог вокала јат поставио је Вук Караџић, и она с незнатним измјенама важе и данас.

Важно је поменути да је пљеваљски говор дио херцеговачког дијалекта новијег типа и да се њиме говори у планинској котлини у долинама ријека Дрине, Таре и Лима, како су то много раније констатовали Гојко Ружичић и Драго Ћупић (уп. Ружичић 1927; Ћупић 1988). Циљ рада је сагледавање односа стандардне ортографске норме и њене ортоепске реализације у Пљевљима, у самом градском језгру. Потрудићемо се да сагледамо степен колебања у односу на досадашњу норму ${ }^{1}$ као и да резултате упоредимо са неким досадашњим истраживањима која су обухватала испитивање говорне праксе и језика писаца са подручја Црне Горе. Анкетирали смо 20 особа, које су наспрам понуђених екавских примјера уписивале ијекавске облике онако како их изговарају у свакодневном го-

1 Као полазиште за стандарднојезичку норму узели смо Правопис српскохрватског књижевног језика са правопсним речником, Матица српска, Нови Сад, 1960; Правопис српског језика, Митар Пешикан, Јован Јерковић, Мато Пижурица, Треће издање, Матица српска, Нови Сад 2013; Речник српског језика, Измењено и поправљено издање, Нови Сад 2011. 
вору. Информанти су рођени и живе у Пљевљима. У питању су одрасле образоване особе и студенти, старосне доби од 23 године до 60 година, генерације рођене, шездесетих, седамдесетих, осамдесетих и деведесетих година ${ }^{2}$.

Неспорно је да се већина варијација у рефлексу јата дешава непосредно иза неког сонанта, при чему се најчешће варијације јављају иза сонаната $p$ и л. Овом приликом ограничићемо се на континуанте старог вокала jam у секвенци $p+$ кратко jam и у секвенци $p+$ дуго јат у говору Пљеваља.

1. Према Правопису, како оном из 1960. тако и у новијем издању из 2013, у кратким слоговима иза групе сугласника чији је посљедњи члан $p$ неутрализована је разлика између екавског и ијекавског изговора (jam je замијењено вокалом е): бреза, брегови, времена, греш$\kappa a .$. Од овог правила постоје и одступања и то неутрализовање разлика и у случајевима када гласу $р$ не претходи сугласник (горе, у смислу навише, резати, репа); али поштујући вуковску традицију Правопис налаже

2 Подаци о ниформантима: Биљана Ђондовић, рођена 1986, дипломирани економиста; Биљана Мрдак, рођена 1978, професор разредне наставе; Васо Ђондовић, 1994, студент; Владимир Ђондовић, 1985, дипломирани правник; Горан Шљукић, 1964, инжењер шумарства; Данко Секулић, 1989, професор енглеског језика; Драгана Бабић, 1984, професор енглеског језика; професор енглеског језика; Иван Грбовић, 1988, професор српског језика; Ивана Ајдуковић, 1984, професор разредне наставе; Ивана Савић 1995, студент; Марина Дамјановић, 1984, професор разредне наставе; Марко Потпарић,1985, дипломирани економиста; Милијана Тошић, 1986, електротехничар рачунара (студирала информационе технологије); Милинко Газдић, 1960, дипломирани инжењер рударства; Милица Савић, 1996, студент; Мирослав Газдић, 1987, струковни економиста; Невена Гашић, 1996, студент; Татјана Машојевић, 1976, машински инжењер; Радмило Марић, 1968, дипломирани инжењер рударства. 
да су исправни само облици горјети, рјечник, рјечит, рјечииа, рјешавати, корјенчић, старјешина и сл. Ипак, у напомени се додаје да су у ијекавским говорима у Црној Гори у овим случајевима широко распрострањени облици са е. Ми смо у анкети наводили екавске облике: у којима је дата сугласничка група са сонантом $p$ као посљедњим чланом + кратко јат (грешка, грешан, стрелица, огрев - табела 1.А), и примјере са сонантом р и кратким јатом (старешина, коренчић, речник, речитост, речит, горети, изгорети, окорели, речавати - табела 1.Б).

\begin{tabular}{|c|c|c|c|c|c|}
\hline & & Грешка & Грешан & Стрелица & Огрев \\
\hline Б. Ђ. & 1986. & Грешка & Грешан & Стрелица & Огрев \\
\hline В. Ђ. & 1985. & Грешка & Грешан & Стрелица & Огрев \\
\hline Б. М. & 1978. & Грешка & Грешан & Стрелица & Огрев \\
\hline Д. С. & 1989. & Грешка & Грешан & Стрелица & Огрјев \\
\hline Г. Ш. & 1964. & Грешка & Грешан & Стријелица & Огрјев \\
\hline Д. Б. & 1984. & Грешка & Грешан & Стрелица & Огријев \\
\hline И. Г. & 1988. & Грешка & Грешан & Стрјелица & Огријев \\
\hline И. А. & 1984. & Грешка & Грешан & стр(ј)елица & Огрев \\
\hline И. С. & 1995. & Грешка & Грешан & Стрелица & Огрјев \\
\hline Н. Г. & 1996. & Грешка & Грешан & стрелица & Огрев \\
\hline М. Д. & 1984. & Грешка & Грешан & стр(ј)елица & Огријев \\
\hline М. П. & 1985. & Грешка & Грешан & Стрелица & Огрјев \\
\hline М. Т. & 1986. & Грешка & Грешан & Стрелица & Огрев \\
\hline М. Г. & 1960. & Грешка & Грешан & Стелица & Огрев \\
\hline М. Г. & 1987. & Грешка & Грешан & Стрелица & Огрев \\
\hline Р. М. & 1968. & Грешка & Грешан & Стрелица & Огријев \\
\hline Т. М. & 1976. & Грешка & Грешан & Стрјелица & Огрјев \\
\hline В. Ђ. & 1985. & Грешка & Грешан & Стрелица & Огрев \\
\hline М. С. & 1996. & Грешка & Грешан & Стрелица & Огрев \\
\hline Р. С. & 1959. & Грешка & Грешан & Стрелица & Огрев \\
\hline
\end{tabular}


1.1. Кад су у питању рефлекси кратког јата иза сугласничке групе чији је посљедњи члан сонант $p$, грађа показује да информанти досљедно употребљавају облике са е у примјерима грешка и грешан, и да је овај рефлекс доминантан и у именици стрелица, коју 15 испитаника користи у овом облику, двоје напоредо употребљавају ликове стрелииа и стрјелица (професори разредне наставе), док само један информант (Г. Ш. инжењер) ову именицу изговара са двосложним рефлексом јата (стријелица). За ову лексему пак Драга Бојовић у раду из 2002. наводи да је у говорима сјевера Црне Горе досљедно облик стрелища, а у истој форми ову именицу у говору Пљевљака интелектуалаца биљежи и Александра Лончар Раичевић 2009. у магистарском раду о фонетско-фонолошкој вриједности јата у ијекавици. Мало више од половине анкетираних, њих 11, именицу огрев употребљава у овом облику, 5 користи облик са секвенцом је, а 4 ову лексему изговара са двосложним рефлексом јата (огријев). Норма такође даје различита рјешења, па је тако у Правопису из 1960. у ијекавском изговору био допуштен лик са $e$ и са је (Правопис 1960: 497), у Правопису из 2013. као нормативан у ијекавском се наводи облик огрев а као дијалекатски дати су облици са је и ије (Правопис 2013: 24). Бранислав Остојић истиче да се у говорима Црне Горе обично употребљава облик огрев, огревни и да је под утицајем говорног језика такав облик устаљенији и у писаној пракси. Јављање облика са двосложним ије у неким народним говорима он сматра аналошким утицајем према глаголу гријати, а према његовом мишљењу норма је упорно форсирала облик са секвенцом је под утицајем Вука Караџића (Остојић 1995а: 95). Према томе, можемо констатовати да је такво досљедно недосљедно стање задржано и до данас у говору образованих Пљевљака, при чему облик са $e$ има незнатну предност у односу на друга два. 


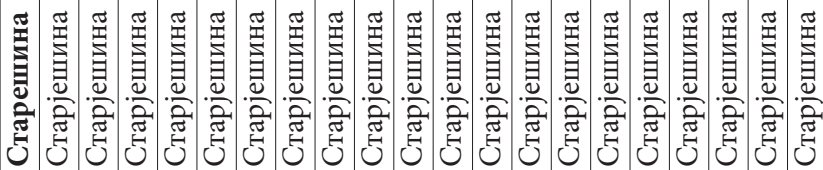

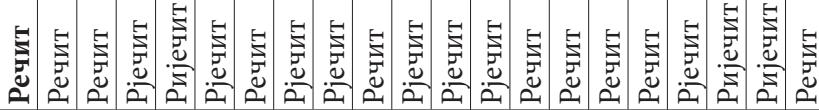

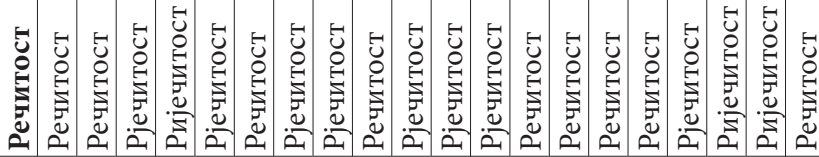

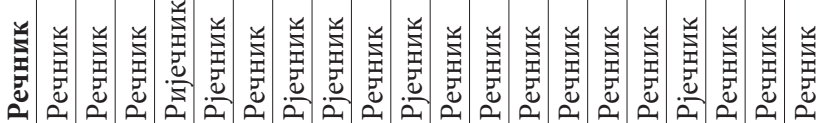

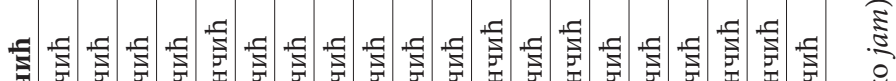
壳

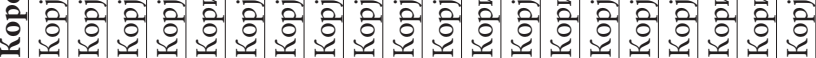

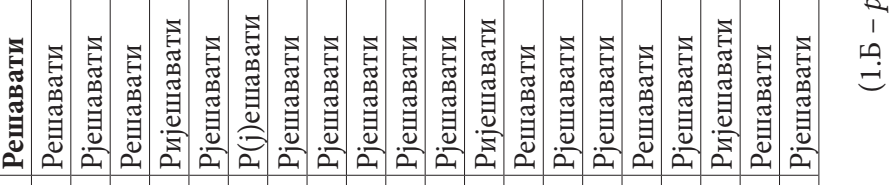

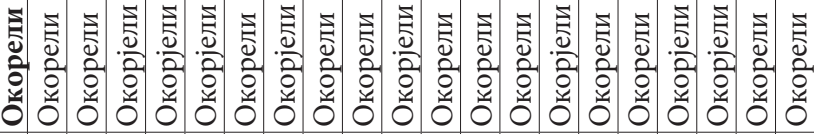

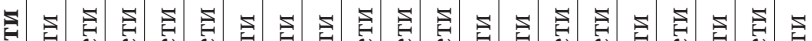
む

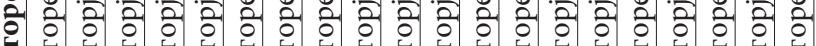

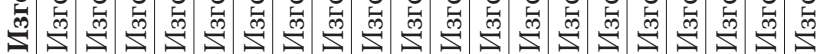

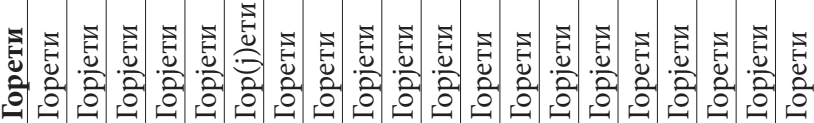

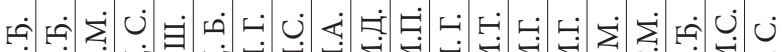
ம் 
1.2. У позицији сонант $p+$ кратко јат секвенца $p j e$ једино је досљедно забиљежена у именици старјешина. Ћупић је пак 1988. године ову лексему у Пљевљима забиљежио само са вокалом $е$ на позицији старог кратког jaта (Ћупић 1988: 83). Четрнаест година касније, 2002. године, Драга Бојовић наводи да су у сјевероцрногорским говорима колебљиви ликови старешина/старјешина, али са ограниченим синтагматским спојевима (старјешина дома, али разредни и војни старешина) (Бојовић 2002: 216). Испитујући дијалекатско и нормативно у језику писаца из Црне Горе, који су стварали крајем 19. вијека и у 20 вијеку, Ана Јањушевић Оливери констатује да се „старији писци углавном приклањају у народним говорима чешћем лику старешина, док млађи користе нормативни лик старјешина" (Јањушевић 2008: 175).

На другом мјесту, са доминантним рефлексом је, у нашем корпусу у овој позицији је именица корјенчић, коју са секвенцом је изговара 15 информаната, а 5 са секвенцом ије. У поменутом раду из 2009. године Лончар Раичевић досљедно биљежи ову лексему са нормативним је (Лончар Раичевић 2009: 43).

Колебања и блага превага рефлекса је потврђени су у глаголима горети, изгорети, решавати који се са секвенцом је јављају у говору 11 испитаника. Вокал $e$ као континуант старог јата у глаголу горети забиљежен је код 8 информаната, у глаголу изгорети код 9, а у глаголу решавати код 6. Осим ових варијација, један испитаник напоредо употребљава облике горети и горјети, а двоје анкетираних је навело двосложно ије код глагола решавати. Колебања у наведеним глаголима биљежи и Лончар Раичевић, с тим што је глагол горети у њеном корпусу чешћи са рефлексом $e$, док код глагола изгорети поред рефлекса $e$ и je, она у говору једног испитаника региструје и рефлекс $u$, глагол pje- 
шавати биљежи доминантно са секвенцом је (Лончар Раичевић 2009: 43). Кад је у питању глагол рјешавати и ријечи изведене од њега, Миодраг Јовановић истиче да је у црногорским народним говорима у употреби екавска варијанта (Јовановић 2005: 85). За разлику од такве говорне праксе, Јањушевић Оливери истиче да се код црногорских писаца у овим случајевима углавном јавља нормативна варијанта са је (Јањушевић 2008: 176). Код писаца из Црне Горе Јањушевић Оливери код глагола горети биљежи облике са је и са $e$ (Јањушевић 2008: 173).

Секвенца е има превласт у именици речник, за шта имамо потврду код 14 испитаника, у 5 случајева биљежимо облик са нормативним је и једном са двосложним ије. Незнатну предност рефлекс е има и у придјеву окорели, у 12 случајева, а код 8 информаната је забиљежен са секвенцом је. Код готово половине испитаника потврђен је рефлекс е у придјеву речит (9), секвенца je у 8 случајева и двосложно ије у 3 примјера. Слична колебања примјећујемо и у именици речитост, која је у овој форми забиљежена код 8 анкетираних Пљевљака, са рефлексом је такође код 8 информаната и са ије код 4. Ћупић је у поменутом истраживању и лексему речито забиљежио само са рефлексом $e$ у Пљевљима. Бојовић са е биљежи: решене, речитост, сагорела (Бојовић 2002: 215). Лончар Раичевић са доминантним е у говору Пљевљака биљежи лексеме окорели и речник, док за придјев речит наводи напоредо ликове са $e$ и са je (Лончар 2009: 42, 43). Јовановић напомиње да је у црногорским говорима заступљен само екавски рефлекс у лексемама речит, речица, речник (Јовановић 2005: 85). Јањушевић Оливери долази до другачијег закључка, кад је у питању писана пракса, па истиче да се црногорски писци у другој половини 20. вијека, након учвршћивања ијекавског стандарда, чешће опредјељују за 
нормативно je, „поготово у лексемама које су књишког поријекла: остарјети, окорјели, закорјели, рјешене, рјечавати, рјеђи, рјечия, рјечник” (Јањушевић 2008: 180).

2. Ријечи изведене префиксом $n p b-$ у српском језику могу имати двосложан или једносложан рефлекс у зависности од дужине вокала jam. У складу с тим двосложан рефлекс најчешће је заступљен код именица и придјева, а једносложан код глагола. Колебања у употреби једног или другог рефлекса најчешће се јављају у именичким лексемама, код којих аналогија све више нарушава правилну замјену дугог јата двосложним ије-рефлексом.

У анкету смо уврстили примјере који су у Правоnuсу из 1960. третирани искључиво дати са а) ије, а у Правопису из 2013. са ије и е (прекор, престо, престониц, и иреступна - табела 2.А); и б) облике који су у оба правописа дати са рефлексима $е$ и ије, тј. као дублети (превоз, превозник, превод, предлог, прећи, прелаз, прелом, пренос, преступ - табела 2.Б). 


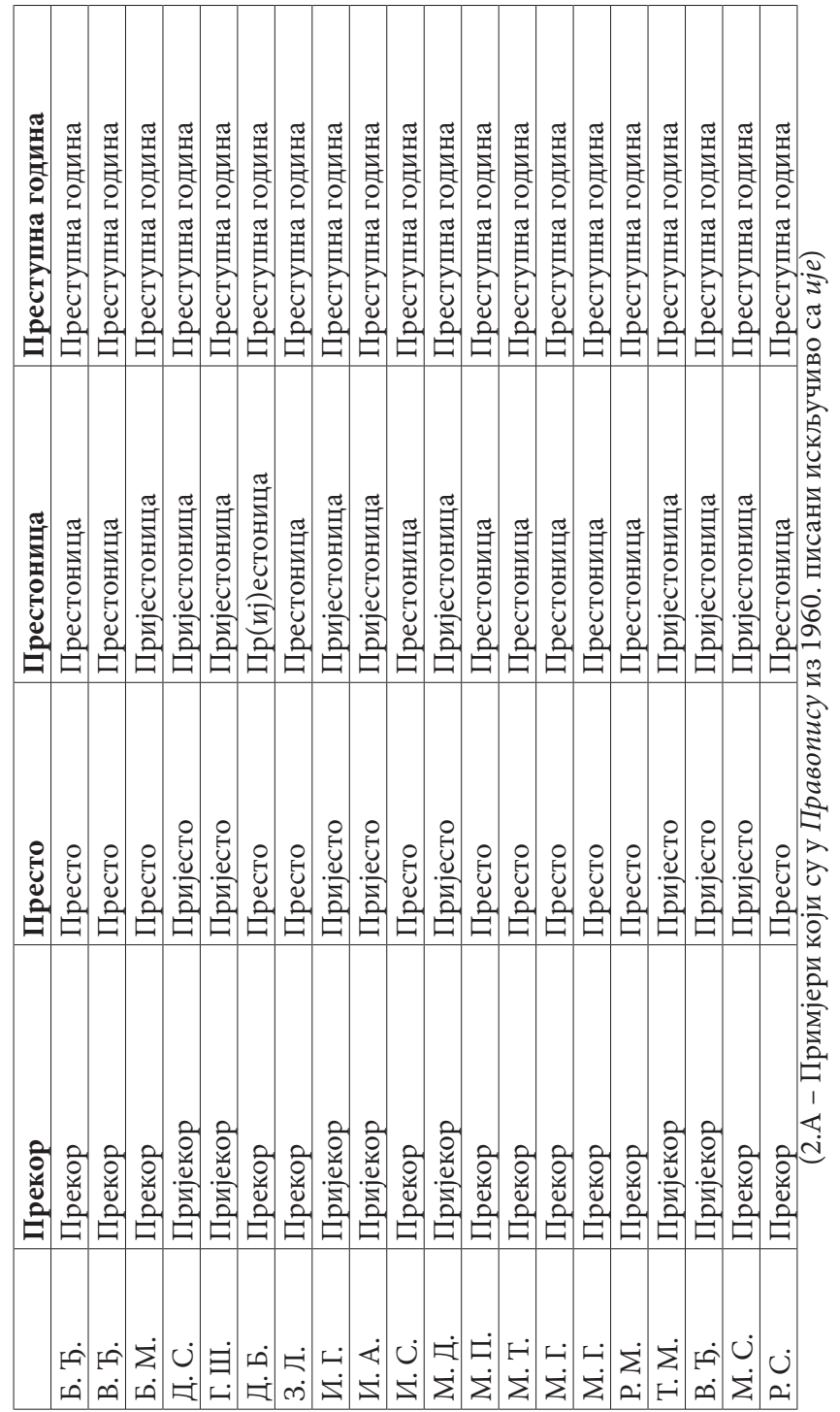




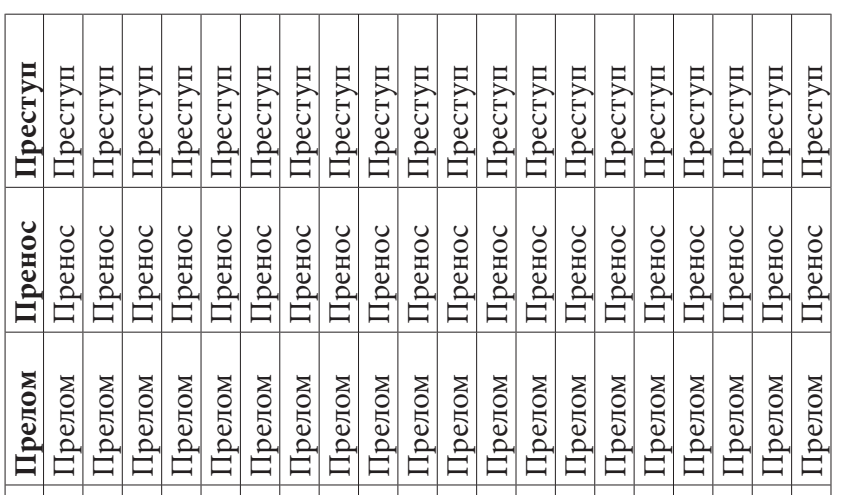

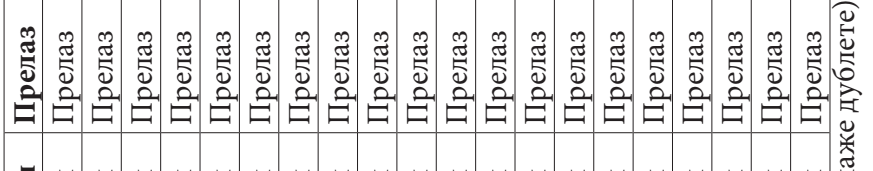

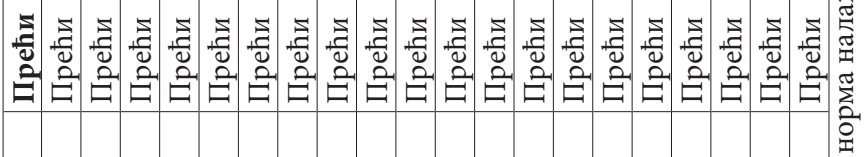

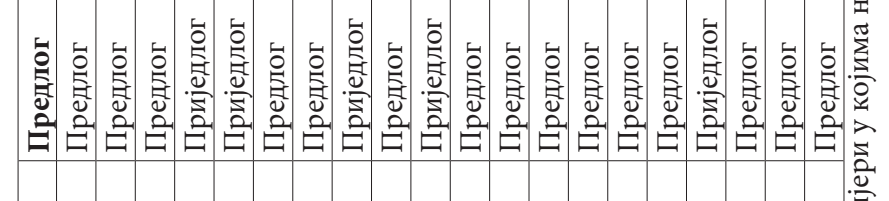

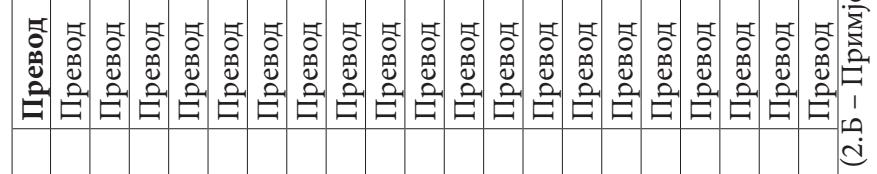

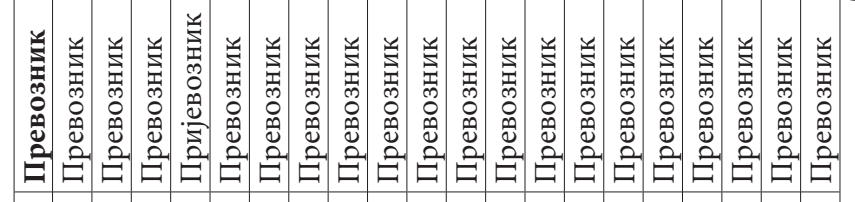

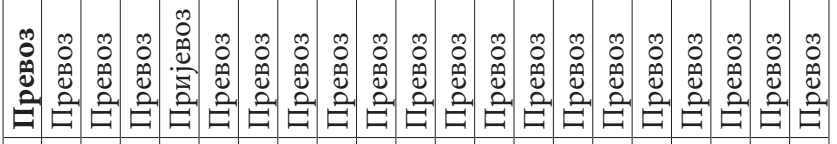

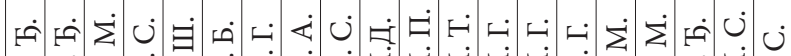

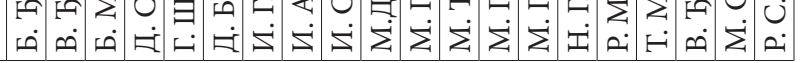


2.1. Кад је у питању префикс пре-, резултати анкете показују сљедеће: са рефлексом $e$ досљедно се јављају именице превод, прелаз, прелом, пренос и престуn, придјев преступна и глагол прећи. Скоро досљедно вокал $е$ потврђен је и у именицама превоз и превозник, чак код 19 испитаника, а само по један анкетирани навео је облике са двосложним ије у овим ријечима. Доминантна превага рефлекса е уочљива је и у облику предлог, који је у овој форми забиљежен код 15 информаната, а код 5 у облику приједлог. Именица прекор се у овој форми јавља код 13 испитаника, а у лику пријекор код њих 7.

Незнатна превага континуанта $e$ забиљежена је и у облику престо, код 12 анкетираних Пљевљака, док облик са ије употребљава 8. Најизраженије колебање у овој групи забиљежено је у именици престоница, која се у овом облику јавља код 10 информаната, 9 користи облик пријестоница и један испитаник је навео да паралелно користи оба облика. Ови наши резултати унеколико показују другачију слику на терену од оне коју је забиљежио Ћупић прије нешто више од тридесет година, и том приликом установио да се на овом подручју вокал $e$ као рефлекс јата јавља, између осталог, и у примјерима: пренос, превоз, прелаз, предлог, престо.

Јовановић констатује да су у изведеницама с префиксом пре- облици са једносложним рефлексом у говорима Црне Горе на путу да потпуно истисну из употребе двосложне, и додаје да се двосложни рефлекс досљедно чува једино у говору старијих и у ријечима из домаћег живота (Јовановић 2005: 87-88).

Слично запажање даје и Ана Јањушевић Оливери и констатује да је у језику црногорских писаца, али и у језику црногорске дневне штампе, видна тенденција потискивања двосложног рефлекса вокала $і$ у префиксалним изведеницама са прї- у корист једносложног $e$. Она појашњава да је „двосложна замјена стабилна [...] 
једино у именицама које су изгубиле везу са мотивним глаголом, па се у њима некадашњи префикс прї- интегрисао са основом, те се данас и не осјећа као префикс (исп. пријеклад). Двосложна замјена нешто је чешћа од једносложне једино у именици пријекор и у глаголу nријећu, док се -ије- у осталим случајевима јавља само спорадично" (Јањушевић 2007: 394-395).

Рефлекс ије у говору Пљевљака у именицама прекор (код једног од пет испитаника) и престо (код четири испитаника) биљежи и Лончар Раичевић (Лончар Раичевић 2009: 47). Постепено продирање двосложног ије у говор Пљевљака посљедњих десетак година у примјерима предлог, престо, престоница, прекор приписали бисмо утицају телевизије у Црној Гори (Јавног сервиса првенствено, а потом и ТВ Вијести), а будући да се ови двосложни рефлекси, међу нашим испитаницима, углавном јављају код просвјетних радника, можемо претпоставити да знатан утицај имају и школски уџбеници, у којима се посљедњих деценија доминантно ови облици пишу са ије иако норма предвиђа дублете.

3.2. У посебну групу издвојили смо глаголе ynompeбити и унапредити и њихове трпне глаголске придјеве употребъен и унапређен, као и глагол стрељати и глаголску именицу стрељаюе у којима стандардна ијекавска норма не допушта варијантне ликове, већ искључиво двосложан рефлекс (табела 2.В). 


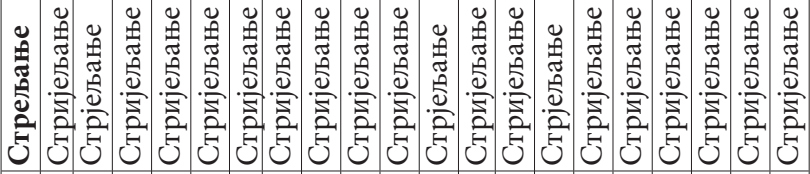

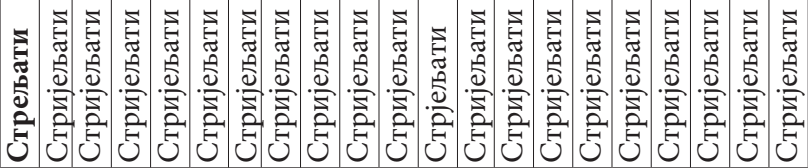

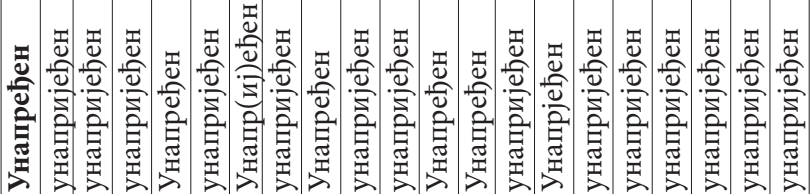

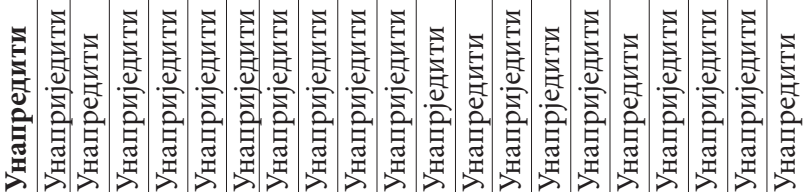



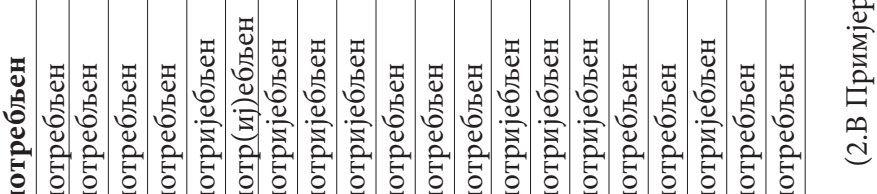

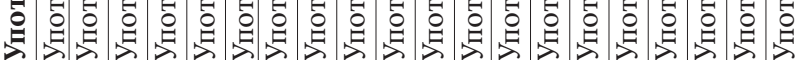

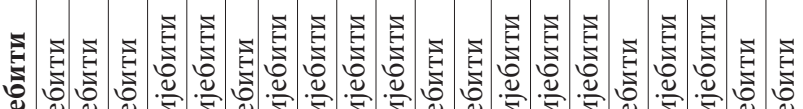

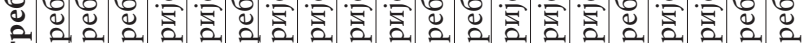

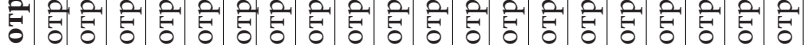

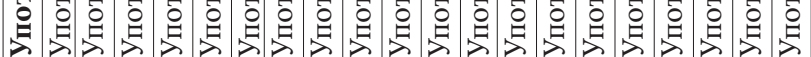

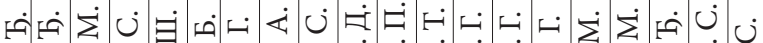
ம் 
Резултати анкете показују превагу двосложних облика, тј. облика рефлексом ије, у свим примјерима, при чему је ова секвенца скоро досљедно заступљена у глаголу стријельати (19 пута и само једном са секвенцом је), потом слиједи именица стријельағе, са 17 оваквих облика и 3 пута са рефлексом је, глагол унаприједити је у овој форми потврђен код 14 испитаника, код 4 информанта је забиљежен рефлекс е у овом глаголу и код 2 испитаника је забиљежена секвенца је; трпни придјев овог глагола са двосложним ије потврђен је такође код 14 информаната, а са рефлексом $e$ код њих 4 , један анкетирани је навео да користи подједнако често облике са ије и $e$, и у једном случају биљежимо секвенцу је. Нешто већа колебања примјетна су код глагола употребити и његовог трпног придјева употребљен. Овај глагол мало више од половине анкетираних, њих 11, користи онако како и ијекавска норма налаже, са рефлексом uje, а облик употребити потврђен је код 9 испитаника. Трпни придјев употреблен са вокалом $e$ као рефлексом старог јата констатован је код 11 анкетираних, а код 8 је потврђен двосложни рефлекс ије и један испитаник подједнако употребљава оба облика.

Остојић на основу својих истраживања долази до закључка да аналошки лик „све више истискује из употребе глаголски облик са дугом замјеном јата, па га у наведеној форми пишу многи савремени црногорски писци који иначе поклањају довољно пажње норми ијекавског писања. Све је чешћи лик са ре и у дневној штампи, као и у језику свакодневне комуникације те нема никаква разлога да се нормативно не прихвати и овај лик" (Остојић 19956: 16). Јањушевић Оливери долази до супротног заључка на основу ексцерпиране грађе из девет књига прозе. „Сви писци, како они старији тако и млађи, употребљавају нормативни системски лик са двосложном замјеном јата. [..] У сваком 
случају, стање регистровано код више репрезентативних црногорских писаца различитих генерација и са различитих подручја показује да је лик са двосложним рефлексом врло стабилан, те да проглашавање екавског лика нормативним (уз регуларни ијекавски) нема оправдања” (Јањушевић 2007: 392).

4. Наши закључци донекле су слични онима до којих је дошла Јањушевић Оливери испитујући писану грађу, тј. да разлог за продирање нормативног је, у позицији сонант $p+$ кратко јаm можемо тражити у утицају норме. Међутим, поставља се питање како објаснити појаву ненормативне секвенце је у именици стрелица и нестандардних облика са ије на мјесту некадашњег кратког јата у лексемама коренчић, решавати, речник, речит, речитост? Иако се ови ненормативни облици јављају спорадично, ипак не треба занемарити чињеницу да је већином ријеч о говору просвјетних радника и студената који живе у градској средини. Претпостављамо да је оваква ситуација резултат деценијског насилног наметања ненормативних ијекавизама у појединим медијима у Црној Гори, као и резултат дјеловања аналогије према исфорсираним облицима са uје у рефлексима дугог јата у школским уџбеницима ${ }^{3}$

3 За ову прилику као изворе користили смо уџбенике Pијеч по ријеч, уџбеник за 5. разред (уредник Душанка Поповић, Дијана Лаковић), Завод за уџбенике и наставна средства, Подгорица, 2019; Ријеч по ријеч, радна свеска за 5. разред, (уредник Душанка Поповић, Дијана Лаковић), Завод за уџбенике и наставна средства, Подгорица, 2011. Познаваюе друштва, уџбеник за 5. разред (ур. Татјана Бурзан, Снежана Турковић, Срђан Вукадиновић), Завод за уџбенике и наставна средства, Подгорица, 2019; Моћ језика 8. разред, (ур. Драгана Ненадовић, Александра Вешовић-Ивановић), Завод за уџбенике и наставна средства, Подгорица, 2011; Моја читанка, Читанка за пети разред основне школе, (ур. Весна Павићевић, Наташа Боровић), Завод за уџбенике и наставна средства, Подгорица, 2011. 
у оним примјерима гдје норма дозвољава дублете (нпр. престо, престоница, предлог...).

Тако поред некадашњег раскорака између норме и говорне праксе, сада долази до новог раскорака између говорне праксе у Црној Гори и језика медија и уџбеника, што доводи до нових колебања у говору образованих људи, а у овом конкретном случају до нових варијација замјене јата.

\section{ЛИТЕРАТУРА}

Белић 2006: А. Белић, Историја српског језика, Четврти том, Београд: Завод за уџбенике и наставна средства.

Бојовић 2002: Д. Бојовић, О неким рефлексима ,јата” у сјеверноцрногорским говорима, Зборник радова са научног скупа „Живот и дјело академика Михаила Стевановића", Научни скупови, књ. 59; Одјељење умјетности, књ. 21, Подгорица: ЦАНУ, 213-218.

Вуковић 1949: J. Vuković, J.: Pravopisna pravila i uputstva za pisanje ijekavskih glasovnih oblika, Svjetlost, Sarajevo.

Јањушевић 2007: А. Јањушевић, Употреба е-рефлекса и колебања у вези са њим у језику писаиа из Црне Горе, Српски језик у (кон)тексту: Зборник радова са научног скупа „Српски језик, књижевност, уметност”, Крагујевац, 385-398.

Јањушевић 2008: А. Јањушевић, Дијалекатско и нормативно у језику писаца из Црне Горе, Језичка ситуаиија у Црној Гори - норма и стандардизаиија, Научни скупови, Књига 87, Одјељење умјетности, Књига 29, Подгорица: ЦАНУ, 161-185.

Јовановић 2005: М. Јовановић, Екавски рефлекс јата у црногорским народним говорима и књижевном језику, Шести лингвистички скуп ,Бошковићеви дани”, Зборници радова, бр. 75, ОУ књ. 23, Подгорица: 83-89. 
Караџић 1818: В. С. Караџић, Српски рјечник истолкован њемачким и латинским ријечима, у Бечу.

Караџић 1852: В. С. Караџић, Српски рјечник истумачен њемачкијем и латинскијем ријечима, у Бечу у штампарији Јерменскога манастира.

Лончар Раичевић 2009: А. Лончар Раичевић, Фонетско-фонолошке вредности јата у ијекавици, магистарска теза, одбрањена 29. 12. 2009. Филолошки факултет Универзитета у Београду.

Остојић 1995а: Б. Остојић, О неким ијекавизмима и њиховим колебањима у норми српског стандардног језика, Научни састанак слависта у Вукове дане, Нормирање српског језика,24/1, Београд: Међународни славистички центар, 89-101.

Остојић 1995б: Б. Остојић: Спорни /и/јекавизми и њихова колебања у норми српског стандардног језика, Puјеч, I/1, Никшић, 2005, 7-29.

Пешикан, Јерковић, Пижурица 2013: М. Пешикан, J. Јерковић, М. Пижурица, Правопис српског језика, Треће издање, Нови Сад : Матица српска.

Правопис 1960: Правопис српскохрватског књижевног језика са правопсним речником, Матица српска-Матица хрватска, Нови Сад - Загреб, 1960.

Речник 2011: Речник српског језика, Измењено и поправљено издање, Нови Сад 2011.

Ружичић 1927: Г. Ружичић, Акценатски систем пљеваљског говора, Српски диалектолошки зборник, Књига III, Расправе и грађа Београд-Земун: Српска краљевска академија, Графички завод „Макарије” АД, 115-176.

Стојановић 2005: Јелица Стојановић, Историја српског језика I, Фонетика; Скрипта за студенте Студијског програма за српски језик и књижевност, Никшић.

Ћупић 1988: Д. Ћупић, Основне особине говора Пљеваља, Гласник одјељења умјетности, Књига 8, Титоград: ЦАНУ, 79-107. 
Jelena Gazdić

\section{SUBSTITUTES OF D VOCAL IN SPEECH IN NORTH OF MONTENEGRO (PLJEVLJA) AND ORTOGRAPHIC NORM}

\section{Summary}

In the paper we deal with the continuants of the old (long and short) vocal $b$ behind sonant $r$ in the speech of Pljevlja. The aim of this paper is to examine the relationship between the standard orthographic norm and its orthoepic realization in Pljevlja, in the city centre. We have tried to look at the degree of fluctuation in relation to the current norm, as well as to compare the results with some studies so far, which included examining the speech practice and language of writers from the territory of Montenegro. We interviewed 20 people, who, in spite of the Ekav examples offered, typed in iekav forms as they are spoken in everyday speech. The informants were born and live in Pljevlja. The reason for the penetration of the normative sequence je instead of the earlier dominant $e$, in the position sonant $r+$ short $b$, can be found in the influence of the norm. The sporadic penetration of non-standard forms instead of the former short vocal $b$ can be explained by the imposition of non-normative forms in certain media, as well as by the action of analogy with the forced forms with $i$ in the reflexes of long vocals $b$ in school textbooks in those cases where the norm permits doublets

Keywords: long flock, short flock, sonant r, Pljevlja 